\title{
Drug therapy in anticoagulation: which drug for which patient?
}

\author{
Authors: Carolyn M Millar ${ }^{\mathrm{A}}$ and Mike A Laffan ${ }^{\mathrm{B}}$
}

Four non-vitamin K oral anticoagulants (NOACs) are now licensed and available in the UK, offering unprecedented choices in anticoagulant therapy for clinicians and patients. NOACs have many clear benefits over warfarin, the most striking being the reduction in intracranial haemorrhage. However, a number of uncertainties remain: their efficacy in certain situations, utility of drug assays, significance of drug interactions and management of bleeding. In the absence of any direct comparative trials, it is not clear that any of the NOACs is significantly better than the others in any of the licensed indications. The differential activities, pharmacokinetics, metabolism, excretion and side effects of the agents should be considered when selecting the most appropriate anticoagulant. In this article, we discuss how, with careful selection for the relevant indication, NOACs can simplify therapy while improving outcomes. We aim to provide clinicians with the information needed to select the most suitable anticoagulant drug for an individual patient in a given situation.

KEYWORDS: Anticoagulant therapy, non-vitamin K oral anticoagulants, NOACs

\section{Introduction}

The non-vitamin K oral anticoagulants (NOACs) ${ }^{1}$ are now established in UK practice and new members continue to arrive. Within their licensed indications they have clear benefits over warfarin, but a number of uncertainties remain: efficacy in some specific situations, the utility of drug assays, significance of drug interactions and the management of bleeding all suffer from a paucity of data.

This article provides an update on developments since the 2014 review in this journal. ${ }^{2}$ Our aim is to provide the information needed to select the most suitable anticoagulant drug for an individual patient in a given situation.

Authors: ${ }^{\text {C }}$ linical senior lecturer, Imperial College, London, UK and consultant haematologist, Imperial College Healthcare NHS Trust, London, UK; ${ }^{B}$ professor of haemostasis and thrombosis, Imperial College, London, UK and honorary consultant in haematology, Imperial College Healthcare NHS Trust, London, UK

\section{Properties of NOACs}

Four NOACs are now licensed and available in the UK: the direct factor $\mathrm{Xa}(\mathrm{FXa})$ inhibitors apixaban, edoxaban and rivaroxaban, and the direct thrombin inhibitor dabigatran. The key to best choice of agent lies in their individual pharmacokinetic profiles, metabolism and routes of excretion. These properties, together with National Institute for Health and Care Excellence (NICE) approved indications, are summarised in Table 1.

\section{Therapeutic indications for NOACs}

\section{Atrial fibrillation}

Summary of phase III NOAC clinical trials in non-valvular atrial fibrillation

The phase III clinical trials comparing NOACs with warfarin for stroke prevention in non-valvular atrial fibrillation (AF) are summarised in Table 2. ${ }^{3-6}$ All NOACs showed non-inferior or increased efficacy for the primary endpoint of stroke or systemic embolism (SSE) with similar or lower major bleeding risk when compared with warfarin. However, efficacy was driven primarily by a reduction in haemorrhagic stroke, while non-inferiority was reached for the reduction in ischaemic stroke. The exception was for the higher dose of dabigatran, which showed superior reduction in ischaemic stroke in all but the best controlled warfarin patients. ${ }^{7}$ Although this was not associated with an increase in major or minor bleeding overall, along with rivaroaxban and high-dose edoxaban there was a significant increase in gastrointestinal bleeding. ${ }^{3}$ The rate of ischaemic stroke did not differ significantly between high-dose edoxaban and warfarin, but was higher with lowdose edoxaban, which has consequently not been licensed. ${ }^{6}$ Apixaban was the only NOAC to show a significant reduction in both SSE and major bleeding compared with warfarin. ${ }^{5}$ These findings were shown to be independent of the quality of international normalised ratio (INR) control in patients receiving warfarin. ${ }^{8}$

\section{Patients with valvular heart disease}

Patients with AF and mechanical prosthetic heart valves or moderate to severe mitral stenosis were excluded from all of the AF trials (Table 2). However, they did include some patients with tissue valve replacements, previous valve repair or other valve disease. These constituted more than 
Table 1. Properties and licensed indications of NOACs

\begin{tabular}{|c|c|c|c|c|}
\hline & Dabigatran & Rivaroxaban & Apixaban & Edoxaban \\
\hline $\begin{array}{l}\text { Mechanism of } \\
\text { action }\end{array}$ & $\begin{array}{l}\text { Direct thrombin } \\
\text { inhibitor }\end{array}$ & Factor Xa inhibitor & Factor $\mathrm{Xa}$ inhibitor & Factor Xa inhibitor \\
\hline$T_{\max }$ & 2 hours & $2-4$ hours & $1-4$ hours & $1-2$ hours \\
\hline $\begin{array}{l}\text { Elimination } \\
\text { half-life }\end{array}$ & $12-17$ hours & $\begin{array}{l}\text { 5-9 hours (young) } \\
11-13 \text { hours (elderly) }\end{array}$ & 12 hours & $10-14$ hours \\
\hline P-gp re-secretion & Yes & Yes & Yes & Yes \\
\hline $\begin{array}{l}\text { CYP3A4 } \\
\text { metabolised }\end{array}$ & No & Yes & Yes & Minimal \\
\hline Renal excretion & Up to $80 \%$ & $66 \%$ & $25 \%$ & $35 \%$ \\
\hline $\begin{array}{l}\text { Plasma protein } \\
\text { binding }\end{array}$ & $35 \%$ & $>90 \%$ & $>90 \%$ & $>90 \%$ \\
\hline $\begin{array}{l}\text { Intake with food } \\
\text { required }\end{array}$ & No & Mandatory & No & No \\
\hline $\begin{array}{l}\text { Hepatic } \\
\text { impairment }\end{array}$ & $\begin{array}{l}\text { Not } \\
\text { recommended } \\
\text { in patients } \\
\text { with elevated } \\
\text { liver enzymes } \\
(>2 \times \cup L N)\end{array}$ & $\begin{array}{l}\text { Contraindicated } \\
\text { in hepatic disease } \\
\text { associated with } \\
\text { coagulopathy and } \\
\text { clinically relevant } \\
\text { bleeding risk, } \\
\text { including cirrhotic } \\
\text { patients classified as } \\
\text { Child-Pugh B and C. }\end{array}$ & $\begin{array}{l}\text { Contraindicated in hepatic disease } \\
\text { associated with coagulopathy and } \\
\text { clinically relevant bleeding risk; } \\
\text { not recommended severe hepatic } \\
\text { impairment (Child-Pugh C); use with } \\
\text { caution in patients with mild (Child- } \\
\text { Pugh A) or moderate (Child-Pugh B) } \\
\text { hepatic impairment or in patients } \\
\text { with elevated liver enzymes (>2×ULN) }\end{array}$ & $\begin{array}{l}\text { Contraindicated in patients } \\
\text { with hepatic disease associated } \\
\text { with coagulopathy and clinically } \\
\text { relevant bleeding risk; not } \\
\text { recommended In patients with } \\
\text { severe hepatic impairment; } \\
\text { use with caution in patients } \\
\text { with mild to moderate hepatic } \\
\text { impairment and patients with } \\
\text { elevated liver enzymes ( }>2 \times U L N)\end{array}$ \\
\hline $\begin{array}{l}\text { Antidote } \\
\text { available }\end{array}$ & Yes & No & No & No \\
\hline \multicolumn{5}{|c|}{ NICE approved indications and doses } \\
\hline NVAF & $\begin{array}{l}150 \mathrm{mg} \mathrm{bd} \\
110 \mathrm{mg} \mathrm{bd}^{1}\end{array}$ & $20 \mathrm{mg} \mathrm{od}^{2}$ & $5 \mathrm{mg} \mathrm{bd}^{3}$ & $60 \mathrm{mg} \mathrm{od}^{3}$ \\
\hline $\begin{array}{l}\text { VTE treatment } \\
\text { and secondary } \\
\text { prevention }\end{array}$ & $\begin{array}{l}150 \text { mg bd } \\
\text { (following } \geq 5 d \\
\text { LMWH) }\end{array}$ & $\begin{array}{l}15 \mathrm{mg} \text { bd (initial } 21 \\
\text { days), } 20 \mathrm{mg} \text { od } \\
\text { after } 21 \text { days }\end{array}$ & $\begin{array}{l}10 \mathrm{mg} \text { bd (initial } 7 \text { days), } 5 \mathrm{mg} \text { bd } \\
\text { (up to } 6 \text { months); } 2.5 \mathrm{mg} \text { bd after } \\
6 \text { months) }\end{array}$ & $\begin{array}{l}60 \mathrm{mg} \text { od (following } \geq 5 \text { days } \\
\text { LMWH) }\end{array}$ \\
\hline $\begin{array}{l}\text { Prevention } \\
\text { of VTE after } \\
\text { elective } \\
\text { hip or knee } \\
\text { replacement }\end{array}$ & $150 \mathrm{mg}$ od & $10 \mathrm{mg}$ od & $2.5 \mathrm{mg} \mathrm{bd}$ & Not licensed \\
\hline ACS & Not licensed & $2.5 \mathrm{mg}$ od & Not licensed & Not licensed \\
\hline
\end{tabular}

${ }^{1}$ Dabigatran $110 \mathrm{mg}$ bd dose in NVAF where $\geq 80$ years; consider where $\mathrm{CrCl} 30-49 \mathrm{~mL} / \mathrm{min}$

${ }^{2}$ Dose reduction rivaroxaban in NVAF: $15 \mathrm{mg}$ od where $\mathrm{CrCl} 30-49 \mathrm{~mL} / \mathrm{min}$

${ }^{3}$ Dose reduction apixaban in NVAF: $2.5 \mathrm{mg}$ bd where $\mathrm{CrCl} 15-29 \mathrm{~mL} / \mathrm{min}$ or where two of serum creatinine $\geq 1.5 \mathrm{mg} / \mathrm{dL}$, age $\geq 80$ years, body weight $\leq 60 \mathrm{~kg}$

${ }^{4}$ Dose reduction edoxaban in NVAF and VTE: $30 \mathrm{mg}$ od where one of $\mathrm{CrCl} 15-49 \mathrm{~mL} / \mathrm{min}$, body weight $\leq 60 \mathrm{~kg}$, concomitant use of cyclosporin, dronedarone, erythromycin or ketoconazole

ACS = acute coronary syndrome; $b d=$ twice per day; $\mathrm{CrCl}=$ creatinine clearance; $\mathrm{LMWH}=$ low molecular weight heparin; NICE = National Institute for Health and Care Excellence; $\mathrm{NOAC}=$ non-vitamin $\mathrm{K}$ oral anticoagulant; $\mathrm{NVAF}=$ non-valvular atrial fibrillation; od = once daily; $\mathrm{P}$-gp $=\mathrm{P}$ glycoprotein; $T_{\max }=$ time to peak level post ingestion; ULN = upper limit of normal; VTE = venous thromboembolism

$25 \%$ of the study population in the ARISTOTLE (Apixaban for Reduction in Stroke and Other Thromboembolic Events in Atrial Fibrillation) trial; the efficacy and safety benefits of apixaban were preserved in these patients despite the greater risk of thromboembolic disease and bleeding associated with both apixaban and warfarin. ${ }^{9}$
Similar findings were obtained with dabigatran ${ }^{10}$ and with rivaroxaban although bleeding was higher in the rivaroxaban arm. ${ }^{11}$ In conclusion, NOACs are a reasonable choice of anticoagulant in patients with AF with some forms of valvular disease taking into account the individual drug properties. ${ }^{12}$ 
Table 2. Non-valvular atrial fibrillation: comparison of NOAC phase III trials

\begin{tabular}{|c|c|c|c|c|}
\hline & RE-LY & ROCKET-AF & ARISTOTLE & ENGAGE-AF \\
\hline Comparison & $\begin{array}{l}\text { Dabigatran } 150 \text { mg bd, } 110 \\
\text { mg bd vs warfarin }\end{array}$ & $\begin{array}{l}\text { Rivaroxaban } 20 \\
\text { mg od vs warfarin }\end{array}$ & $\begin{array}{l}\text { Apixaban } 5 \mathrm{mg} \mathrm{bd} \\
\text { vs warfarin }\end{array}$ & $\begin{array}{l}\text { Edoxban } 60 \mathrm{mg} \text { od, } 30 \mathrm{mg} \\
\text { od vs warfarin }\end{array}$ \\
\hline Patients, $\mathrm{n}$ & 18,113 & 14,264 & 18,201 & 21,105 \\
\hline Study design & $\begin{array}{l}\text { Double blind, open-label with } \\
\text { blinded endpoint evaluation }\end{array}$ & $\begin{array}{l}\text { Double blind, } \\
\text { double dummy }\end{array}$ & $\begin{array}{l}\text { Double blind, } \\
\text { double dummy }\end{array}$ & $\begin{array}{l}\text { Double blind, double } \\
\text { dummy }\end{array}$ \\
\hline $\begin{array}{l}\text { Reduced dose for selected } \\
\text { patients }\end{array}$ & - & $\begin{array}{l}15 \text { mg od: } \mathrm{CrCl} \\
30-49 \mathrm{~mL} / \mathrm{min}\end{array}$ & $\begin{array}{l}2.5 \mathrm{mg} \text { bd where } \\
\text { two of: }\end{array}$ & $\begin{array}{l}\text { Dose halved ( } 30 \text { mg, } 15 \\
\text { mg) where one of: }\end{array}$ \\
\hline & & & $\begin{array}{l}>\text { serum creatinine } \\
\geq 1.5 \mathrm{mg} / \mathrm{dL} \\
>\text { age } \geq 80 \text { years } \\
>\text { body weight } \\
\leq 60 \mathrm{~kg}\end{array}$ & $\begin{array}{l}>\mathrm{CrCl} 30-50 \mathrm{~mL} / \mathrm{min} \\
>\text { body weight } \leq 60 \mathrm{~kg} \\
>\text { concomitant verapamil, } \\
\text { quinidine or dronedarone }\end{array}$ \\
\hline Mean patient age, years & 71 & 73 & 70 (median) & 72 \\
\hline Mean $\mathrm{CHADS}_{2}$ score & 2.1 & 3.5 & 2.1 & 2.8 \\
\hline Mean time in therapeutic range, $\%$ & 64.0 & 55.0 & 62.2 & 64.9 \\
\hline Valve exclusion & Severe valve disorder & $\begin{array}{l}\text { Significant MS; } \\
\text { any prosthesis }\end{array}$ & $\begin{array}{l}\text { Moderate/Severe } \\
\text { MS; mechanical }\end{array}$ & $\begin{array}{l}\text { Moderate/Severe MS; } \\
\text { mechanical }\end{array}$ \\
\hline Paroxysmal AF, \% & 32 & 18 & 15 & 25 \\
\hline $\begin{array}{l}\text { Primary endpoint SSE } \\
\text { HR }(95 \% \mathrm{CI})^{*}\end{array}$ & $\begin{array}{l}150 \mathrm{mg}: 0.65(0.52-0.81)^{\mathrm{s}} \\
110 \mathrm{mg}: 0.90(0.74-1.10)\end{array}$ & $0.88(0.75-1.03)$ & $0.79(0.66-0.95)^{5}$ & $\begin{array}{l}60 \mathrm{mg}: 0.79(0.63-0.99) \\
30 \mathrm{mg}: 1.07(0.87-1.31)\end{array}$ \\
\hline $\begin{array}{l}\text { Ischaemic stroke } \\
\mathrm{HR}(95 \% \mathrm{CI})^{*}\end{array}$ & $\begin{array}{l}150 \mathrm{mg}: 0.76(0.60-0.98)^{\mathrm{s}} \\
110 \mathrm{mg}: 1.11(0.89-1.40)\end{array}$ & $0.94(0.75-1.17)$ & $0.92(0.74-1.13)$ & $\begin{array}{l}60 \text { mg: } 1.00(0.83-1.19) \\
30 \text { mg: } 1.41(1.19-1.67)\end{array}$ \\
\hline $\begin{array}{l}\text { Major bleeding } \\
\text { HR }(95 \% \mathrm{CI})^{*}\end{array}$ & $\begin{array}{l}150 \mathrm{mg}: 0.93(0.81-1.07) \\
110 \mathrm{mg}: 0.80(0.70-0.93)^{5}\end{array}$ & $1.04(0.90-1.20)$ & $0.69(0.60-0.80)^{5}$ & $\begin{array}{l}60 \text { mg: } 0.80(0.71-0.91) \\
30 \text { mg: } 0.47(0.41-0.55)\end{array}$ \\
\hline $\begin{array}{l}\text { Major gastrointestinal bleeding } \\
\text { HR }(95 \% \mathrm{CI})^{*}\end{array}$ & $\begin{array}{l}150 \text { mg: } 1.48 \text { (1.18-1.85) } \\
110 \text { mg: } 1.08 \text { (0.85-1.38) }\end{array}$ & $1.61(1.30-1.99)$ & $0.89(0.70-1.15)$ & $\begin{array}{l}60 \mathrm{mg}: 1.23(1.02-1.50) \\
30 \mathrm{mg}: 0.67(0.53-0.83)^{5}\end{array}$ \\
\hline $\begin{array}{l}\text { Intracranial bleeding } \\
\mathrm{HR}(95 \% \mathrm{CI})^{*}\end{array}$ & $\begin{array}{l}150 \mathrm{mg}: 0.40(0.27-0.60)^{\mathrm{s}} \\
110 \mathrm{mg}: 0.31(0.20-0.47)^{\mathrm{s}}\end{array}$ & $0.67(0.47-0.93)^{5}$ & $0.42(0.30-0.58)^{s}$ & $\begin{array}{l}60 \mathrm{mg}: 0.47(0.34-0.63)^{5} \\
30 \mathrm{mg}: 0.30(0.21-0.43)^{5}\end{array}$ \\
\hline Reduction in all-cause mortality & $\begin{array}{l}150 \text { mg: } 0.88 \text { (0.77-1.00) } \\
110 \text { mg: } 0.91(0.80-1.03)\end{array}$ & $0.85(0.70-1.02)$ & $0.89(0.80-0.99)$ & $\begin{array}{l}60 \text { mg: No } \\
30 \text { mg: Yes }\end{array}$ \\
\hline \multicolumn{5}{|c|}{$\begin{array}{l}\text { All comparisons versus warfarin and reached non-inferiority, unless otherwise stated. } \\
\text { *Data for dabigratran are presented as relative risk ( } 95 \% \mathrm{CI}) \\
\text { SSuperior } \\
\mathrm{AF}=\text { atrial fibrillation; } \mathrm{CHADS}_{2}=\text { congestive heart failure, hypertension history, age } \geq 75 \text { years, diabetes mellitus history, stroke or symptoms of transient ischaemic } \\
\text { attack; } \mathrm{CI}=\text { confidence interval; } \mathrm{CrCl}=\text { creatinine clearance; } \mathrm{HR}=\text { hazard ratio; } \mathrm{MS}=\text { mitral stenosis; } \mathrm{NOAC}=\text { non-vitamin } \mathrm{K} \text { oral anticoagulant; } \mathrm{SSE}=\text { stroke or } \\
\text { systemic embolism }\end{array}$} \\
\hline
\end{tabular}

In contrast, a trial comparing dabigatran to warfarin in patients following mechanical aortic or mitral valve replacement was terminated prematurely because of an excess risk of thromboembolic and bleeding complications in the dabigatran patients. ${ }^{13}$ Warfarin remains the anticoagulant of choice in patients with mechanical heart valves.

\section{Patients undergoing cardioversion}

The use of NOAC or warfarin was not associated with any difference in ischaemic or bleeding events in the AF trial participants undergoing cardioversion. ${ }^{14-16}$ This was reproduced in a prospective study of cardioversion comparing rivaroxaban with warfarin. ${ }^{17}$ Trans-oesophageal echocardiography was performed according to standard protocols ${ }^{18}$ and patients with left atrial thrombus were excluded. ${ }^{17}$

\section{Criticisms of the AF trials}

The manufacturers of dabigatran were criticised for withholding RE-LY (Randomized Evaluation of Long-term anticoagulant therapy) analyses that suggested that a major bleeding risk might be significantly reduced (with minimal effect on risk of ischaemic stroke) if dabigatran plasma levels were monitored and the dose adjusted accordingly. ${ }^{19}$ The lower bioavailability of dabigatran and its administration as a pro-drug to facilitate absorption may account for the greater variability in plasma levels observed between patients taking dabigatran compared with the other NOACs. ${ }^{20}$ Concerns regarding the validity of ROCKET-AF (Rivaroxaban Once Daily Oral Direct Factor Xa Inhibition Compared with Vitamin K Antagonism for Prevention of Stroke and Embolism Trial in Atrial Fibrillation) data have recently been raised 
following recognition that the device used to monitor INR and administer warfarin dosage was faulty; in some cases it led to inflated doses of warfarin with consequent increased bleeding rates. $^{21,22}$ Subsequent investigations by the US Food and Drug Administration (FDA) and European Medicines Agency (EMA) have determined the effects on stroke and bleeding risk to be minimal and insufficient to alter the trial findings.

\section{Interpretation of trial findings}

The AF studies differed somewhat in design, risk profile of participants and in outcome definitions, but results were broadly similar (Table 2). Nonetheless, in the absence of direct comparative head-to-head trials these differences may be significant. For example, both ARISTOTLE and RE-LY recruited fewer patients with heart failure or hypertension than ROCKET-AF and ENGAGE-AF (Effective Anticoagulation with Factor Xa Next Generation in Atrial Fibrillation-Thrombolysis in Myocardial Infarction 48): consequently, in ROCKET-AF over $85 \%$ of patients had a $\mathrm{CHADS}_{2}$ (congestive heart failure, hypertension history, age $\geq 75$ years, diabetes mellitus history, stroke or symptoms of transient ischaemic attack) score $\geq 3$ compared with 53\% in ENGAGE-AF and 32\% in RE-LY, while no ROCKET-AF patients had scores $0-1$ compared with $32 \%$ in RE-LY.

Indirect comparative analyses have shown no significant difference in ischaemic stroke rates between NOACs, with the exception of the higher rate seen with edoxaban $30 \mathrm{mg} .{ }^{23,24}$ Major bleeding was shown on indirect analyses to be significantly lower in apixaban when compared with dabigatran $150 \mathrm{mg}$ (reduced by $26 \%$ ), rivaroxaban (by $34 \%$ ) and edoxaban $60 \mathrm{mg}$ (by 21\%). ${ }^{23,24}$ Indirect comparison between apixaban and dabigatran $110 \mathrm{mg}$ found no difference in major bleeding risk, while bleeding is higher in apixaban when compared with edoxaban $30 \mathrm{mg}^{23,24}$

While European guidance advocates a preference for NOACs over warfarin for stroke prevention in patients with nonvalvular AF, ${ }^{25}$ NICE guidance in the UK recommends that the decision between NOAC and warfarin be based on the patient's clinical features and preferences following discussion of the options. ${ }^{26}$ This discussion will include how the individual characteristics of the patient match those of the individual anticoagulant.

\section{Acute coronary syndrome}

In patients with acute coronary syndrome (ACS), apixaban and dabigatran in addition to antiplatelet therapy resulted in unfavourable efficacy and safety profiles. ${ }^{27,28}$ A lower dose of rivaroxaban ( $2.5 \mathrm{mg}$ twice per day) in combination with dual antiplatelet therapy significantly improved ischaemic outcome in ACS, including rates of stent thrombosis, ${ }^{29}$ albeit with an associated increase in bleeding; ${ }^{30}$ this indication for rivaroxaban is licensed and approved in the UK.

\section{Venous thromboembolism}

Initial venous thromboembolism treatment

Phase III randomised controlled trials showed the noninferiority of NOACs to low molecular weight heparin (LMWH) plus warfarin (or equivalent vitamin K antagonist) in preventing recurrent symptomatic venous thromboembolism (VTE) or death from VTE (Table 3) ${ }^{31-35}$ As with the AF trials, there was an overall reduction in major, fatal and intracranial bleeding. ${ }^{31-36}$ Unlike the AF trials, the risk of gastrointestinal bleeding did not appear to be increased when compared with warfarin, possibly reflecting less comorbidity in the younger population in these trials.

A key practical difference between NOACs is that dabigatran and edoxaban were both given after 5 days of conventional LMWH therapy, whereas apixaban and rivaroxaban were given as single agents throughout with higher doses given for the initial 7 and 21 days, respectively (Table 3). ${ }^{31-35}$

Again, there were differences in trial duration, outcome definition, blinding status and patient characteristics: for example the apixaban cohort in the AMPLIFY (Apixaban for the Initial Management of Pulmonary Embolism and DeepVein Thrombosis as First-Line Therapy) trial were older and included lower numbers of cancer patients (Table 3). Around $90 \%$ of patients in AMPLIFY had unprovoked VTE; this was lower for EINSTEIN and Hokusai-VTE, suggesting some variation in baseline VTE risk (Table 3). Nonetheless, all four NOACs are licensed and approved for the acute treatment of VTE (Table 3).

\section{Prevention of recurrent VTE}

The extension trials of apixaban, rivaroxaban and dabigatran for secondary prevention of VTE, following an initial anticoagulation period of 6 months after a first VTE episode, were all carried out against placebo in patients where the indication for long-term anticoagulation was uncertain (Table 4). ${ }^{32,33,37,38}$ Dabigatran is the only agent to be also trialled against warfarin for patients definitely requiring anticoagulation (RE-MEDY, Table 4). ${ }^{38}$

Compared with placebo, all four significantly reduced VTE recurrence without excessive bleeding rates. In the AMPLIFY-EXT (Apixaban after the Initial Management of Pulmonary Embolism and Deep Vein Thrombosis with First-Line Therapy-Extended Treatment) study, the bleeding rate with $2.5 \mathrm{mg}$ apixaban twice per day was not significantly different from placebo. It is likely that the low bleeding rates with these agents will reduce the threshold at which patients at risk of recurrent VTE will benefit from long-term anticoagulation.

In the RE-MEDY trial, dabigatran $150 \mathrm{mg}$ twice per day was shown to be non-inferior to warfarin in preventing fatal or recurrent VTE in patients requiring long-term anticoagulation, with an associated reduction in significant bleeding. ${ }^{38}$ There have been no studies of dabigatran $110 \mathrm{mg}$ twice per day in the treatment or secondary prevention of VTE.

As yet, data are not available for patients with recurrent VTE, cerebral venous sinus thrombosis, portal vein thrombosis or other unusual sites and NOACs are not licensed for these indications. Moreover, there are no data to indicate whether NOAC dosing can be increased to match a target INR of $>2.5$.

\section{Cancer}

Cancer is associated with a high risk of VTE recurrence and recommended treatment is with $\mathrm{LMWH}$, based largely on the results of the CLOT (Comparison of Low Molecular Weight Heparin Versus Oral Anticoagulant Therapy for 
Table 3. Venous thromboembolism initial treatment: comparison of NOAC phase III trials

\begin{tabular}{|c|c|c|c|c|}
\hline & $\begin{array}{l}\text { RE-COVER I } \\
\text { RE-COVER II }\end{array}$ & $\begin{array}{l}\text { EINSTEIN-DVT } \\
\text { EINSTEIN-PE }\end{array}$ & AMPLIFY & Hokusai-VTE \\
\hline Comparison & $\begin{array}{l}\text { Dabigatran } 150 \\
\text { mg bd vs LMWH/ } \\
\text { warfarin }\end{array}$ & $\begin{array}{l}\text { Rivaroxaban } 15 \mathrm{mg} \text { bd } \\
21 \text { days, then } 20 \mathrm{mg} \text { od } \\
\text { vs LMWH/warfarin or VKA }\end{array}$ & $\begin{array}{l}\text { Apixaban } 10 \mathrm{mg} \\
\text { bd } 7 \text { days, then } 5 \\
\text { mg bd vs LMWH/ } \\
\text { warfarin }\end{array}$ & $\begin{array}{l}\text { Edoxaban } 60 \mathrm{mg} \\
\text { od } 30 \mathrm{mg} \mathrm{od}^{1} \mathrm{vs} \\
\text { LMWH/warfarin }\end{array}$ \\
\hline Patients, $\mathrm{n}$ & $\begin{array}{l}\text { RE-COVER I: } 2,564 \\
\text { RE-COVER II: } 2,568\end{array}$ & $\begin{array}{l}\text { EINSTEIN-DVT: } 3,449 \\
\text { EINSTEIN-PE: 4,832 }\end{array}$ & 5,400 & 8,292 \\
\hline Study design & $\begin{array}{l}\text { Double blind, } \\
\text { double dummy }\end{array}$ & Open-label & Double blind, & $\begin{array}{l}\text { Double blind, } \\
\text { double dummy }\end{array}$ \\
\hline Patient age, years & $\begin{array}{l}55.0 \text { (median) } \\
54.7\end{array}$ & $\begin{array}{l}55.8 \text { (mean) } \\
57.9\end{array}$ & 57.2 & 55.8 (mean) \\
\hline Unprovoked VTE, \% & NS & $\begin{array}{l}60.9 \\
64.7\end{array}$ & 89.8 & 65.9 \\
\hline Cancer, \% & 4.8 & 7.0 & 2.5 & 9.2 \\
\hline Heparin lead-in & At least 5 days & None & None & At least 5 days \\
\hline Treatment duration & 6 months & $\begin{array}{l}\text { Pre-specified } \\
3,6 \text {, or } 12 \text { months }\end{array}$ & 6 months & $\begin{array}{l}\text { Flexible } \\
3-12 \text { months }\end{array}$ \\
\hline $\begin{array}{l}\text { Recurrent VTE or VTE-related death HR } \\
(95 \% \mathrm{CI})^{*}\end{array}$ & $\begin{array}{l}1.10(0.65-1.84) \\
1.08(0.64-1.80)\end{array}$ & $\begin{array}{l}0.68(0.44-1.04) \\
1.12(0.75-1.68)\end{array}$ & $0.84(0.60-1.18)$ & $0.89(0.70-1.13)$ \\
\hline $\begin{array}{l}\text { Major bleeding } \\
\text { HR }(95 \% \mathrm{CI})^{*}\end{array}$ & $\begin{array}{l}0.82(0.45-1.48) \\
0.69(0.36-1.32)\end{array}$ & $\begin{array}{l}0.65(0.33-1.30) \\
0.49(0.31-0.79)\end{array}$ & $0.31(0.17-0.55)$ & $0.84(0.59-1.21)$ \\
\hline $\begin{array}{l}\text { Major or clinically relevant non-major } \\
\text { bleeding HR }(95 \% \mathrm{CI})^{*}\end{array}$ & $\begin{array}{l}0.63(0.51-0.77) \\
0.62(0.45-0.84)\end{array}$ & $\begin{array}{l}0.97(0.76-1.22) \\
0.90(0.76-1.07)\end{array}$ & $0.44(0.36-0.55)$ & $0.81(0.71-0.94)$ \\
\hline Intracranial bleeding, \% (warfarin/VKA) & $0.1(0.2)$ & NS & $0.1(0.2)$ & $0.1(0.4)$ \\
\hline Gastrointestinal bleeding, \% (warfarin/VKA) & $4.0(2.8)$ & NS & $0.3(0.7)$ & NS \\
\hline
\end{tabular}

Table 4. Prevention of recurrent venous thromboembolism: comparison of NOAC phase III trials

\begin{tabular}{|c|c|c|c|c|}
\hline & RE-SONATE & RE-MEDY & EINSTEIN-EXT & AMPLIFY-EXT \\
\hline Comparison & $\begin{array}{l}\text { Dabigatran } 150 \text { mg bd } \\
\text { vs placebo }\end{array}$ & $\begin{array}{l}\text { Dabigatran } 150 \text { mg bd } \\
\text { vs warfarin }\end{array}$ & $\begin{array}{l}\text { Rivaroxaban } 20 \mathrm{mg} \\
\text { od vs placebo }\end{array}$ & $\begin{array}{l}\text { Apixaban } 2.5 \mathrm{mg} \text { or } 5 \mathrm{mg} \\
\text { bd vs placebo }\end{array}$ \\
\hline Patients, n & 1,343 & 2,856 & 1,196 & 2,482 \\
\hline $\begin{array}{l}\text { Treatment duration before } \\
\text { randomisation }\end{array}$ & $\begin{array}{l}6-18 \text { months of VKA or } \\
\text { dabigatran }\end{array}$ & $\begin{array}{l}\text { 3-12 months of VKA } \\
\text { or dabigatran }\end{array}$ & $\begin{array}{l}6 \text { or } 12 \text { months of } \\
\text { VKA or rivaroxaban }\end{array}$ & $\begin{array}{l}6-12 \text { months of standard } \\
\text { therapy or apixaban }\end{array}$ \\
\hline Treatment length, months & 6 & $6-36$ & 6 or 12 & 12 \\
\hline $\begin{array}{l}\text { Recurrent VTE } \\
\operatorname{HR}(95 \% \mathrm{CI})^{*}\end{array}$ & $0.08(0.02-0.25)^{1}$ & $1.44(0.78-2.64)^{2}$ & $0.18(0.09-0.39)$ & $\begin{array}{l}2.5 \mathrm{mg}: 0.33(0.22-0.48)^{3} \\
5 \mathrm{mg}: 0.36(0.25-0.53)^{3}\end{array}$ \\
\hline $\begin{array}{l}\text { Major bleeding } \\
\text { HR }(95 \% \mathrm{CI})^{*}\end{array}$ & NE & $0.52(0.27-1.02)$ & NE & $\begin{array}{l}2.5 \mathrm{mg}: 0.49(0.09-2.64) \\
5 \mathrm{mg}: 0.25(0.03-2.24)\end{array}$ \\
\hline $\begin{array}{l}\text { Major or clinically relevant } \\
\text { non-major bleeding } \\
\text { HR }(95 \% \mathrm{CI})^{*}\end{array}$ & $2.92(1.52-5.60)$ & $0.54(0.41-0.71)$ & $5.19(2.30-11.70)$ & $\begin{array}{l}2.5 \mathrm{mg}: 1.20(0.69-2.10) \\
5 \mathrm{mg}: 1.62(0.96-2.73)\end{array}$ \\
\hline
\end{tabular}


Long Term Anticoagulation in Cancer Patients With Venous Thromboembolism) trial. ${ }^{39}$ A small number of patients with cancer were included in the VTE phase III trials (2-9\%, Table 3), and pooled data suggest a significantly lower VTE recurrence in cancer patients receiving NOACs compared with warfarin. ${ }^{36}$ However, this should not be extrapolated to all cancer patients because of inter-trial variation in cancer definition and exclusion of cancer patients deemed to require LMWH. Moreover, the potential for unreliable absorption and gastrointestinal toxicity of NOACs as well as drug interactions means that LMWH remains the treatment of choice in cancerassociated VTE.

\section{Antiphospholipid syndrome}

Around $10 \%$ of venous thromboembolic events occur in the context of the antiphospholipid syndrome (APS); ${ }^{40}$ this patient subgroup was not specifically addressed in the VTE treatment trials and would not have entered the placebo controlled extension studies. A randomised clinical study comparing rivaroxaban and warfarin in over 100 APS patients with previous VTE showed the endogenous thrombin potential to be increased but the peak thrombin to be reduced in the rivaroxaban arm after 42 days of treatment. ${ }^{41}$ The clinical significance of these results is not yet known. No data are available on NOACs in APS patients with arterial thrombosis; warfarin remains the anticoagulant of choice for both venous and arterial thrombosis in the APS setting.

\section{NOACs and comorbidities}

Age

Thrombotic and bleeding risks both increase significantly with age but there is a differential interaction with NOACs. ${ }^{42,43}$ Investigations by the FDA and EMA have concluded that reported post-marketing increased bleeding rates in older patients taking dabigatran are consistent with the bleeding rates reported in RE-LY, in which the reduced risk of bleeding shown with dabigatran $110 \mathrm{mg}$ was limited to patients $<75$ years of age, with bleeding risks similar to warfarin in patients $\geq 75$ years. ${ }^{3}$ However, the reduction in intracranial haemorrhage (ICH) with both dabigatran doses was shown to be independent of patient age. Dabigatran $110 \mathrm{mg}$ is the recommended dose for AF patients $\geq 80$ years of age, and should also be considered in patients $\geq 75$ years (Table 5); this dose is not licensed for treatment of VTE.

Similar increases in bleeding with age have also been seen with edoxaban $60 \mathrm{mg}^{6}$ and rivaroxaban; ${ }^{44}$ neither specifies dose adjustment. The lower risk of bleeding seen with apixaban compared with warfarin in ARISTOTLE prevailed in all age categories, including those aged $\geq 75$ years; ${ }^{5}$ apixaban dose reduction is recommended in patients $\geq 80$ years of age in conjunction with an additional risk factor (Table 5).

\section{Bleeding}

All phase III studies in AF and VTE have shown there to be fewer bleeding complications with NOACs than warfarin

Table 5. Dosing in non-valvular atrial fibrillation: renal function, age and body weight

\begin{tabular}{|c|c|c|c|c|}
\hline & Dabigatran & Rivaroxaban & Apixaban & Edoxaban \\
\hline Standard dose & $150 \mathrm{mg} \mathrm{bd}$ & $20 \mathrm{mg} \mathrm{bd}$ & $5 \mathrm{mg} \mathrm{bd}$ & $60 \mathrm{mg}$ od \\
\hline Renal function & & & & \\
\hline $\mathrm{CrCl} 30-49 \mathrm{~mL} / \mathrm{min}$ & Consider $110 \mathrm{mg} b d$ & $15 \mathrm{mg}$ od & $5 \mathrm{mg} b d$ & $30 \mathrm{mg}$ od \\
\hline $\mathrm{CrCl} 15-29 \mathrm{~mL} / \mathrm{min}$ & Not recommended & Use with caution & $2.5 \mathrm{mg} \mathrm{bd}$ & $30 \mathrm{mg}$ od \\
\hline $\mathrm{CrCl}<15 \mathrm{~mL} / \mathrm{min}$ & Not recommended & Not recommended & Not recommended & Not recommended \\
\hline $\mathrm{CrCl}>95 \mathrm{~mL} / \mathrm{min}$ & - & - & - & Not recommended \\
\hline Age & $\begin{array}{l}\geq 80 \text { years: } 110 \mathrm{mg} \text { bd } \\
\geq 75 \text { years: consider } 110 \mathrm{mg} \mathrm{bd}\end{array}$ & - & $\begin{array}{l}2.5 \mathrm{mg} \text { bd where two of: } \\
>\text { serum creatinine } \geq 1.5 \mathrm{mg} / \mathrm{dL} \\
>\text { age } \geq 80 \text { years } \\
>\text { weight } \leq 60 \mathrm{~kg}\end{array}$ & - \\
\hline Body weight & - & - & $\begin{array}{l}2.5 \mathrm{mg} \text { bd where two of: } \\
>\text { serum creatinine } \geq 1.5 \mathrm{mg} / \mathrm{dL} \\
>\text { age } \geq 80 \text { years } \\
>\text { weight } \leq 60 \mathrm{~kg}\end{array}$ & $\begin{array}{l}30 \text { mg od: } \\
>\text { weight } \leq 60 \mathrm{~kg}\end{array}$ \\
\hline Others & $\begin{array}{l}100 \text { mg bd: } \\
>\text { concomitant verapamil } \\
>\text { consider where increased risk } \\
\text { of bleeding }\end{array}$ & & & $\begin{array}{l}30 \text { mg od: } \\
\text { > concomitant use } \\
\text { of cyclosporine, } \\
\text { dronedarone, } \\
\text { erythromycin or } \\
\text { ketoconazole }\end{array}$ \\
\hline
\end{tabular}


(reaching non-inferiority or superiority, Tables 2 and 3), with the outcome of bleeding appearing less serious in patients receiving NOACs. ${ }^{45,46}$ Particularly striking is the reduction in ICH (around 50\%) and other life-threatening bleeding. ${ }^{47}$ The exception is gastrointestinal (GI) bleeding, which appears to vary considerably between NOACs with several studies showing higher GI bleeding risks than warfarin (Tables 2 and 3). The significantly higher incidence (approximately 1.5 fold) of GI bleeding with dabigatran $150 \mathrm{mg}$ compared with warfarin found in $\mathrm{RE}-\mathrm{LY}^{3}$ has been reproduced in most post-marketing studies. ${ }^{48,49}$ However, 12-month post-approval follow-up of a Danish registry cohort of over 14,000 anticoagulant naïve patients has shown both dabigatran doses to have comparable or lower GI bleeding rates than warfarin although these patients were younger and with lower $\mathrm{CHADS}_{2}$ scores than the RE-LY patients. ${ }^{50}$ A higher rate of GI bleeding symptoms was also shown in the rivaroxaban patients in ROCKET-AF ${ }^{4}$ although rates of life-threatening and fatal GI bleeds were comparable to warfarin ${ }^{44}$ and far fewer rivaroxaban-associated major GI bleeds met the criteria for life-threatening GI bleeding than for dabigatran $150 \mathrm{mg}$ in the RE-LY trial (13\% versus 50\%). In contrast, a direct comparison between dabigatran $150 \mathrm{mg}$ twice per day and rivaroxaban $20 \mathrm{mg}$ once daily in over 100,000 'real world' patients with non-valvular AF has shown the risks of ICH and major extracranial bleeding, including major GI bleeding, to be significantly increased in patients treated with rivaroxaban. ${ }^{51}$ The risk of GI bleeding in ENGAGE-AF was also shown to be significantly higher with edoxaban $60 \mathrm{mg}$ compared with warfarin, ${ }^{6}$ while no difference in GI bleeding was found between the apixaban and warfarin patients in ARISOTLE, ${ }^{5}$ or dabigatran $110 \mathrm{mg}$ and warfarin patients in RE-LY. ${ }^{3}$

As discussed above, the risk of major GI bleeding in the VTE studies was not increased compared with warfarin, possibly reflecting the younger population with fewer comorbidities in these trials. Overall, the risk of GI bleeding or underlying GI pathology is an important consideration when selecting a NOAC.

The different rates of GI bleeding between NOACs may reflect incomplete absorption of NOACs and persistence of active anticoagulant within the GI lumen following oral ingestion. Why the GI bleeding risks should differ between the direct FXa inhibitors is not clear; it is possible that this may in part reflect differences in $\mathrm{P}$-glycoprotein (P-gp) transportation and peak anticoagulant concentration, which themselves are dependent on metabolism and dosing regimen.

\section{Renal impairment}

Patients with chronic kidney disease (CKD) are at an increased risk of both VTE and bleeding. ${ }^{52}$ Moreover, it has been suggested that the relative benefit of NOACs may be greater in patients with mild and moderate CKD than those with normal renal function. ${ }^{53}$ European licensing in AF requires dose adjustment of NOACs in patients with renal impairment with parallel consideration of patient age, weight and concomitant medications (Table 5). Renal function should be checked annually in uncomplicated patients, with more frequent testing advocated in patients with any impairment of renal function (eg creatinine clearance $(\mathrm{CrCl})<60 \mathrm{~mL} / \mathrm{min}$ ) and older or frail patients. ${ }^{12}$ Although there is a lack of comparative data showing differences in risks from CKD between NOACs, the suitability of agent may be guided by the clear differences in renal dependence (Table 1). Trial data may also help choice; for example, the lower rates of venous and bleeding complications with apixaban compared with warfarin have been shown to be independent of renal function. ${ }^{54}$ Moreover, the relative reduction in bleeding with apixaban compared with warfarin has been shown to be greater in patients with impaired renal function as defined by $\mathrm{CrCl}<50 \mathrm{~mL} / \mathrm{min}^{54}$ The lower bleeding rates observed with edoxaban compared with warfarin in patients with normal renal function are also seen in patients with renal impairment, ${ }^{55}$ while this has not been shown to be the case for dabigatran $110 \mathrm{mg},{ }^{56}$ which has greater renal dependence. Poor renal function is a key predictor of bleeding in patients taking dabigatran. ${ }^{57}$

These findings suggest that selected NOAC use may be preferable to warfarin in some patients with CKD. NICE guidance suggests that use of apixaban should be considered in preference to warfarin in patients with mild/moderate CKD as defined by glomerular filtration rate of $30-50 \mathrm{~mL} / \mathrm{min} .{ }^{58}$ There are currently insufficient data and experience to advocate the use of any of the NOACs in patients with $\mathrm{CrCl}<15 \mathrm{~mL} / \mathrm{min}$ or in patients on haemodialysis. At the other end of the spectrum, the relative efficacy of edoxaban in stroke prevention has been shown to be reduced in patients with higher $\mathrm{CrCl}^{55}$ leading to summary of product characteristics (SmPC) advice to avoid edoxaban where $\mathrm{CrCl}>95 \mathrm{~mL} / \mathrm{min}$ (Table 5).

\section{Patients with hepatic impairment}

All NOACs are contraindicated in patients with hepatic disease associated with coagulopathy and should be avoided in patients with severe hepatic impairment. Suitability in patients with mild and moderate hepatic impairment varies between NOACs (Table 1).

\section{Drug-drug interactions}

Despite being significantly fewer with NOACs than warfarin, there are a number of interactions that require appreciation when deciding upon NOAC suitability and dosage for an individual patient. The availability of pharmacokinetic data is continually expanding, but for many drugs currently remains insufficient to make specific recommendations. The role of drug assays in these circumstances is considered later in this article. Potential drug interactions should be considered in the context of other risk factors for bleeding that include age ( $\geq 75$ years), body weight $(<60 \mathrm{~kg})$ and renal function (Table 5). Common to all NOACs is the potential for increased plasma levels when taken in combination with drugs that compete for the P-gp transporter, such as the frequently used antiarrhythmics verapamil, amiodarone and quinidine; dose reduction may be required, in particular with dabigatran or edoxaban. ${ }^{12}$ Increased rivaroxaban levels may result from CYP3A4 inhibition, ${ }^{59}$ whereas the CYP3A4 pathway makes minimal contribution towards edoxaban clearance and is not involved at all in the clearance of dabigatran. The diverse nature of non-renal clearance of apixaban reduces the impact of any CYP3A4 interactions, ${ }^{60}$ such that use of apixaban should be avoided only when drugs that strongly inhibit both CYP3A4 and P-gp are used, such as the HIV protease inhibitors and 
azole antifungals. On the other hand, potent inducers of P-gp and CYP3A4, such as rifampicin and carbamazepine are likely to lower NOAC plasma levels to subtherapeutic levels. Proton pump inhibitors and antacids do not modify the clinical effects of NOACs.

\section{Antiplatelet therapy}

As with warfarin, the increased bleeding risk when NOACs are used together with antiplatelet agents is significant and an incremental increase in major bleeding risk results from the addition of a NOAC is added to single or dual antiplatelet agent, for example in the management of ACS. ${ }^{27,28,30,61}$ There are presently insufficient available data to optimally guide clinical practice in such settings. All phase III AF trials allowed concomitant use of aspirin; however, only RE-LY included a substantial number of patients taking dual antiplatelet therapy (aspirin and clopidogrel) in addition to dabigatran. ${ }^{61}$ Although antiplatelet use was associated with an increased risk of bleeding, the benefit of dabigatran over warfarin was not impacted significantly. There are currently no large-scale randomised studies evaluating the use of newer antiplatelet agents, such as prasugrel and ticagrelor, in combination with either NOAC or warfarin.

\section{Ischaemic heart disease}

Myocardial infarction (MI) risk appeared to be higher in the dabigatran than warfarin arm for both dabigatran doses in RE-LY although the difference was not shown to be statistically significant. ${ }^{3}$ A subsequent meta-analysis of seven dabigatran trials across indications has similarly shown a higher MI event rate with dabigatran than warfarin with an absolute excess of around 3 per 1,000 patients; again this did not reach levels of statistical significance. ${ }^{62}$ No difference in event rate was seen when RE-LY data were analysed using aggregated cardiac events (ACS, cardiac arrest or death) in addition to $\mathrm{MI},{ }^{63}$ nor did the cardiac event rate associated with dabigatran appear to differ between patients with or without known ischaemic heart disease. ${ }^{63}$ The Danish registry cohort, described earlier, reported lower MI rates in patients taking dabigatran than warfarin, ${ }^{50}$ while switching from warfarin to dabigatran has been shown to increase the MI risk compared with continued warfarin usage. ${ }^{64}$ A significant excess of MI has not been demonstrated for the FXa inhibitors. ${ }^{4-6}$ This is despite the higher absolute numbers of MIs seen in the edoxaban and rivaroxaban arms in the ENGAGE-AF and ROCKET-AF trials, respectively. ${ }^{4,6}$ No increased MI risk was shown with apixaban in the ARISTOTLE trial. ${ }^{5}$

\section{INR control}

Meta-analyses of the AF trials have shown NOACs to have a greater impact on reducing the risk of major bleeding when compared with patients taking warfarin in centres with poorer INR control as measured by time in therapeutic range (TTR) $<66 \%$. $^{65}$ As discussed earlier, the quality of INR control has been shown to impact on the relative benefit of dabigatran. ${ }^{7}$ The beneficial effect of edoxaban also appears greater when compared to patients with poorer INR control, while similar effects are not seen with rivaroxaban or apixaban; apixaban offered a benefit on risk of stroke, bleeding or mortality irrespective of TTR in the comparator warfarin arm. ${ }^{8}$ Studies have not identified a level of TTR with which warfarin is more effective than NOACs.

\section{Practical applications}

\section{Measuring anticoagulant effect}

A major advantage of the NOACs over warfarin is their fixed dosing without need for monitoring. However, there are times at which assessment of drug exposure and anticoagulant effect may be required, eg serious bleeding or urgent surgery, deterioration in renal function, consideration for thrombolysis, extremes of body weight or with certain concomitant medications. In general, the activated partial thromboplastin time (APTT) may provide a qualitative indication of the presence of direct thrombin inhibitors and the prothombin time (PT) the FXa inhibitors; however, there is considerable variability in the sensitivity of these assays between laboratories and the patient response. Importantly, normal PT and APTT times may be obtained in the presence of therapeutic amounts of NOACs. Although often not performed as part of the routine coagulation screen, a normal thrombin time can be interpreted as indicating minimal circulating concentration of dabigatran.

While quantitation of NOAC concentration is now available, using either anti-Xa assays (for FXa inhibitors) or a dilute thrombin time (for direct thrombin inhibitors), the utility of these assays is also limited by a lack of data correlating them with bleeding risk and the absence of defined therapeutic ranges. Moreover, significant inter-patient variability in NOAC levels has been reported, ${ }^{20,66-68}$ and there is poor interlaboratory agreement in quality assurance exercises. Access to these assays may not yet be routinely available, particularly out of hours, in which case clinical decision making should be based on the time of last dose, half-life and renal function (Table 1).

Specific guidance regarding laboratory measurement of NOACs is provided by the British Committee for Standards in Haematology. ${ }^{69}$

\section{Management of bleeding complications}

The approach to management of bleeding again require an appreciation of the pharmacokinetic properties of the NOACs, including their relatively short half-lives (Table 1). This is of particular importance where quantitative assays are not readily available. In normal subjects, haemostasis can be expected to be approaching normal at 24 hours following the last NOAC dose; however, consideration should be given to individual patient characteristics, such as renal impairment and concomitant medication.

The low protein binding of dabigatran facilitates its removal by dialysis although the effectiveness is not known and clinical evidence is limited. ${ }^{70,71}$ Plasma levels of FXa inhibitors are not significantly reduced by dialysis. The only specific reversal agent currently available is idarucizumab, which should be used in patients who develop life-threatening bleeding while taking dabigatran. Life-threatening bleeding in patients receiving FXa inhibitors can be treated with prothrombin complex concentrates or the bypassing agents recombinant factor VIIa or factor eight inhibitor bypassing agent. Support for their use 
is limited, being largely derived from the effect on haemostatic parameters in NOAC-treated animal models. In one study, 50 $\mathrm{u} / \mathrm{kg}$ of prothrombin complex concentrate was able to return bleeding after skin biopsy to normal in healthy volunteers receiving edoxaban. ${ }^{72}$ There is less evidence for use of factor eight inhibitor bypassing agent or factor VIIa and a concern that such pre-activated agents may increase thrombotic events.

\section{Antidotes}

Idarucizumab, a humanised monoclonal antibody antigenbinding fragment that binds to dabigatran, is the first available NOAC antidote and should be used to restore haemostasis in patients presenting with serious bleeding or requiring urgent surgery. ${ }^{73}$ Clinical trials showed near complete dabigatran reversal within minutes ${ }^{74,75}$ and normal peak and trough plasma levels of dabigatran have been shown following recommencement of dabigatran 24 hours following idarucizumab administration. ${ }^{76}$ Antidotes to the FXa inhibitors are in various stages of development; these include andexanet alfa, a recombinant human FXa analogue that binds to the FXa inhibitors but lacks procoagulant activity. ${ }^{77}$ Studies in healthy volunteers taking standard doses of apixaban and rivaroxaban showed loss of anticoagulant activity within minutes of andexanet infusion. ${ }^{78}$ However, both measures subsequently increased, necessitating infusion of andexant over a 2-hour period to sustain suppression. ${ }^{78}$ Trials of andexanet in patients presenting with bleeding while receiving FXa inhibitors are currently underway with dose calculated according to the type of FXa inhibitor and, for rivaroxaban, the time from last dose, but this relies on obtainment of accurate clinical information. ${ }^{79}$ While preliminary analysis has shown achievement of effective haemostasis in $79 \%$ of patients, thrombotic events occurred in 18\%; notably, there was no comparator control arm. ${ }^{79}$ A less specific reversal agent, ciraparantag - a small, synthetic molecule that binds to heparin through noncovalent interactions - also binds to the NOACs, and has thus far been shown to successfully reverse the anticoagulant effect of edoxaban. ${ }^{80}$

\section{Perioperative management}

It is generally recommended that NOACs be omitted for 24 hours prior to low-risk surgical procedures and 48 hours prior to high-risk procedures in patients with normal renal function. ${ }^{81}$ For patients with impaired renal function, it is advised that this interval be prolonged by 24 hours (or longer for dabigatran). ${ }^{81}$ Patients undergoing procedures that carry a high bleeding risk should not recommence full dose postoperative anticoagulation until $48-72$ hours following the procedure. ${ }^{81}$

\section{Thrombolysis in ischaemic stroke}

Thrombolytic therapy with recombinant tissue plasminogen activator is not recommended in patients receiving warfarin with INR $>1.7$. The bleeding risks associated with thrombolysis in patients receiving NOACs are currently unknown. Patients taking dabigatran can be given idaracizumab. It is unlikely that plasma drug levels will be available within the approved time frame for thrombolysis so for FXa inhibitors, judgement relies on timing of most recent dose together with patient characteristics; in the absence of available evidence, it has been suggested that thrombolytic therapy not be given within 24-48 hours following last NOAC dose. ${ }^{82}$

\section{Extremes of body weight}

There are limited data on the efficacy and safety of fixed dose therapy at extremes of body weight. The apixaban and edoxaban SmPCs both recommend dose reduction at low body weight (Table 5). Reduced drug exposure, lower peak concentrations and shorter half-lives have been shown with increasing body weight ${ }^{83}$ although their clinical relevance is unknown and there is high inter-patient variability as well as a lack of defined therapeutic ranges for NOAC drug levels. In the absence of randomised controlled trials, evidence is drawn from subgroup analyses of patients included in the large phase III clinical trials and the effect of body weight on pharmacokinetic parameters of NOACs. Guidance recommends that NOACs be avoided in patients with a body mass index greater than 40 $\mathrm{kg} / \mathrm{m}^{2}$ or those who weigh more than $120 \mathrm{~kg} .{ }^{83}$ Where NOACs are used in these patients, measurement of peak and trough drug levels is recommended and where the level is lower than expected, the patient should be switched to warfarin. ${ }^{83}$

\section{Conclusion}

The new direct acting oral anticoagulants offer significant advantages to both patients and doctors. Carefully chosen for the relevant indication, they can simplify therapy while improving outcomes. In the absence of any direct comparative trials, it is not clear whether any of the agents are significantly better than the others in any of the licensed indications. However, it is clear that they have differences in activity, pharmacokinetics, metabolism, excretion and side effects that can make appropriate patient selection critical. Careful screening of patients for bleeding diatheses (especially GI bleeding), concomitant medications, renal function and age are all important. The benefits and problems of once daily dosage regimens remain moot. Widespread acceptance has undoubtedly been limited by the lack of a reversal agent but this is now being addressed and post-marketing data show better outcomes from NOAC- than warfarin-associated bleeding even without this, confirming the overall benefit of the new agents. The most striking benefit, although unexplained, is the reduction in ICH compared with warfarin. We wait to discover how far the indications for NOACs will extend and whether they will be valuable for patients requiring more intensive anticoagulation than the standard INR of 2.5.

\section{Conflicts of interest}

CMM has received travel support from Boehringer Ingelheim, Leopharma, NovoNordisk, Pfizer and SOBI, speakers fees from Leopharma, LFB and Pfizer, and consultancy fees from Shire. MAL has received travel support from LFB and Bayer, speaker fees from Pfizer, Leopharma and Bayer and consultancy fees from SOBI.

\section{Acknowledgements}

CMM and MAL are supported by the NIHR Imperial College Biomedical Research Centre. 


\section{References}

1 Lip GY, Camm AJ, Hylek EM, Halperin JL, Weitz JI. Non-vitamin K antagonist oral anticoagulants: an appeal for consensus on terminology. Chest 2014;145:1177-8.

2 Thachil J. The newer direct oral anticoagulants: a practical guide. Clin Med 2014;14:165-75.

3 Connolly SJ, Ezekowitz MD, Yusuf S et al. Dabigatran versus warfarin in patients with atrial fibrillation. $N$ Engl J Med 2009;361:1139-51.

4 Patel MR, Mahaffey KW, Garg J et al. Rivaroxaban versus warfarin in nonvalvular atrial fibrillation. N Engl J Med 2011;365:883-91.

5 Granger CB, Alexander JH, McMurray JJ et al. Apixaban versus warfarin in patients with atrial fibrillation. $N$ Engl J Med 2011;365:981-92.

6 Giugliano RP, Ruff CT, Braunwald E et al. Edoxaban versus warfarin in patients with atrial fibrillation. $N$ Engl J Med 2013;369:2093-104.

7 Wallentin L, Yusuf S, Ezekowitz MD et al. Efficacy and safety of dabigatran compared with warfarin at different levels of international normalised ratio control for stroke prevention in atrial fibrillation: an analysis of the RE-LY trial. Lancet 2010;376:975-83.

8 Wallentin L, Lopes RD, Hanna M et al. Efficacy and safety of apixaban compared with warfarin at different levels of predicted international normalized ratio control for stroke prevention in atrial fibrillation. Circulation 2013;127:2166-76.

9 Avezum A, Bahit MC, Hermosillo JA et al. Apixaban in patients with atrial fibrillation: patient characteristics of The Latin America cohort from a multinational clinical trial. Value Health 2015;18:A809.

10 Ezekowitz MD, Nagarakanti R, Noack H et al. Comparison of dabigatran and warfarin in patients with atrial fibrillation and valvular heart disease: the RE-LY trial (randomized evaluation of long-term anticoagulant therapy). Circulation 2016;134:589-98.

11 Breithardt G, Baumgartner H, Berkowitz SD et al. Clinical characteristics and outcomes with rivaroxaban vs warfarin in patients with non-valvular atrial fibrillation but underlying native mitral and aortic valve disease participating in the ROCKET AF trial. Eur Heart J 2014;35:3377-85.

12 Heidbuchel H, Verhamme P, Alings $M$ et al. Updated European Heart Rhythm Association Practical Guide on the use of nonvitamin $\mathrm{K}$ antagonist anticoagulants in patients with non-valvular atrial fibrillation. Europace 2015;17:1467-507.

13 Eikelboom JW, Connolly SJ, Brueckmann M et al. Dabigatran versus warfarin in patients with mechanical heart valves. $N$ Engl J Men 2013;369:1206-14.

14 Nagarakanti R, Ezekowitz MD, Oldgren J et al. Dabigatran versus warfarin in patients with atrial fibrillation: an analysis of patients undergoing cardioversion. Circulation 2011;123:131-6.

15 Flaker G, Lopes RD, Al-Khatib SM et al. Efficacy and safety of apixaban in patients after cardioversion for atrial fibrillation: insights from the ARISTOTLE Trial (Apixaban for Reduction in Stroke and Other Thromboembolic Events in Atrial Fibrillation). J Am Coll Cardiol 2014;63:1082-7.

16 Piccini JP, Stevens SR, Lokhnygina Y et al. Outcomes after cardioversion and atrial fibrillation ablation in patients treated with rivaroxaban and warfarin in the ROCKET AF trial. J Am Coll Cardiol 2013;61:1998-2006.

17 Cappato R, Ezekowitz MD, Klein AL et al. Rivaroxaban vs vitamin $\mathrm{K}$ antagonists for cardioversion in atrial fibrillation. Eur Heart $J$ 2014;35:3346-55.

18 Camm AJ, Lip GY, De Caterina R et al. 2012 focused update of the ESC Guidelines for the management of atrial fibrillation: an update of the 2010 ESC Guidelines for the management of atrial fibrillation. Developed with the special contribution of the European Heart Rhythm Association. Eur Heart J 2012;33:2719-47.
19 Cohen D. Dabigatran: how the drug company withheld important analyses. BMJ 2014;349:g4670.

20 Chan NC, Coppens M, Hirsh J et al. Real-world variability in dabigatran levels in patients with atrial fibrillation. J Thromb Haemost 2015;13:353-9.

21 Cohen D. Rivaroxaban: can we trust the evidence? BMJ 2016;352:i575.

22 Patel MR, Hellkamp Fox AS Committee KA Investigators RAE. Point-of-care warfarin monitoring in the ROCKET AF trial. $N$ Engl J Med 2016;374:785-8.

23 Lip GY, Larsen TB, Skjoth F, Rasmussen LH. Indirect comparisons of new oral anticoagulant drugs for efficacy and safety when used for stroke prevention in atrial fibrillation. J Am Coll Cardiol 2012;60:738-46.

24 Skjoth F, Larsen TB, Rasmussen LH, Lip GY. Efficacy and safety of edoxaban in comparison with dabigatran, rivaroxaban and apixaban for stroke prevention in atrial fibrillation. An indirect comparison analysis. Thromb Haemost 2014;111:981-8.

25 Kirchhof P, Benussi S, Kotecha D et al. 2016 ESC Guidelines for the management of atrial fibrillation developed in collaboration with EACTS. Eur Heart J 2016;37:2893-962.

26 National Institute for Health and Care Excellence. Atrial fibrillation: management. NICE clinical guideline No 180. London: NICE, 2017.

27 Oldgren J, Wallentin L, Alexander JH et al. New oral anticoagulants in addition to single or dual antiplatelet therapy after an acute coronary syndrome: a systematic review and meta-analysis. Eur Heart J 2013;34:1670-80.

28 Alexander JH, Lopes RD, James S et al. Apixaban with antiplatelet therapy after acute coronary syndrome. $\mathrm{N}$ Engl J Med 2011;365:699-708.

29 Gibson CM, Chakrabarti AK, Mega J et al. Reduction of stent thrombosis in patients with acute coronary syndromes treated with rivaroxaban in ATLAS-ACS 2 TIMI 51. J Am Coll Cardiol 2013;62:286-90.

30 Mega JL, Braunwald E, Wiviott SD et al. Rivaroxaban in patients with a recent acute coronary syndrome. N Engl J Med 2012;366:9-19.

31 Schulman S, Kearon C, Kakkar AK et al. Dabigatran versus warfarin in the treatment of acute venous thromboembolism. N Engl J Med 2009;361:2342-52.

32 EINSTEIN Investigators, Bauersachs R, Berkowitz SD et al. Oral rivaroxaban for symptomatic venous thromboembolism. $N$ Engl J Med 2010;363:2499-510.

33 EINSTEIN-PE Investigators, Buller HR, Prins MH et al. Oral rivaroxaban for the treatment of symptomatic pulmonary embolism. $N$ Engl J Med 2012;366:1287-97.

34 Agnelli G, Buller HR, Cohen A et al. Oral apixaban for the treatment of acute venous thromboembolism. $N$ Engl J Med 2013;369:799-808.

35 Hokusai VTEI, Buller HR, Decousus H et al. Edoxaban versus warfarin for the treatment of symptomatic venous thromboembolism. N Engl J Med 2013;369:1406-15.

36 van Es N, Coppens M, Schulman S, Middeldorp S, Buller HR. Direct oral anticoagulants compared with vitamin $\mathrm{K}$ antagonists for acute venous thromboembolism: evidence from phase 3 trials. Blood 2014;124:1968-75.

37 Agnelli G, Buller HR, Cohen A et al. Apixaban for extended treatment of venous thromboembolism. N Engl J Med 2013;368:699708.

38 Schulman S, Kearon C, Kakkar AK et al. Extended use of dabigatran, warfarin, or placebo in venous thromboembolism. N Engl J Med 2013;368:709-18.

39 Lee AY, Levine MN, Baker RI et al. Low-molecular-weight heparin versus a coumarin for the prevention of recurrent venous thromboembolism in patients with cancer. N Engl J Med 2003;349:146-53.

40 Andreoli L, Chighizola CB, Banzato A et al. Estimated frequency of antiphospholipid antibodies in patients with pregnancy morbidity, 
stroke, myocardial infarction, and deep vein thrombosis: a critical review of the literature. Arthritis Care Res 2013;65:1869-73.

41 Cohen $\mathrm{H}$, Hunt BJ, Efthymiou M et al. Rivaroxaban versus warfarin to treat patients with thrombotic antiphospholipid syndrome, with or without systemic lupus erythematosus (RAPS): a randomised, controlled, open-label, phase 2/3, non-inferiority trial. Lancet Haematol 2016;3:e426-36.

42 Harper P, Young L, Merriman E. Bleeding risk with dabigatran in the frail elderly. N Engl J Med 2012;366:864-6.

43 Legrand M, Mateo J, Aribaud A et al. The use of dabigatran in elderly patients. Arch Intern Med 2011;171:1285-6.

44 Goodman SG, Wojdyla DM, Piccini JP et al. Factors associated with major bleeding events: insights from the ROCKET AF trial (rivaroxaban once-daily oral direct factor Xa inhibition compared with vitamin $\mathrm{K}$ antagonism for prevention of stroke and embolism trial in atrial fibrillation). J Am Coll Cardiol 2014;63:891-900.

45 Majeed A, Hwang HG, Connolly SJ et al. Management and outcomes of major bleeding during treatment with dabigatran or warfarin. Circulation 2013;128:2325-32.

46 Hylek EM, Held C, Alexander JH et al. Major bleeding in patients with atrial fibrillation receiving apixaban or warfarin: the ARISTOTLE trial (Apixaban for Reduction in Stroke and Other Thromboembolic Events in Atrial Fibrillation): predictors, characteristics, and clinical outcomes. J Am Coll Cardiol 2014;63:2141-7.

47 Hart RG, Diener HC, Yang S et al. Intracranial hemorrhage in atrial fibrillation patients during anticoagulation with warfarin or dabigatran: the RE-LY trial. Stroke 2012;43:1511-7.

48 Graham DJ, Reichman ME, Wernecke M et al. Cardiovascular, bleeding, and mortality risks in elderly Medicare patients treated with dabigatran or warfarin for nonvalvular atrial fibrillation. Circulation 2015;131:157-64.

49 Hernandez I, Zhang Y. Risk of bleeding with dabigatran in 20102011 medicare data. JAMA Intern Med 2015;175:1245-7.

50 Larsen TB, Rasmussen LH, Skjoth F et al. Efficacy and safety of dabigatran etexilate and warfarin in "real-world" patients with atrial fibrillation: a prospective nationwide cohort study. J Am Coll Cardiol 2013;61:2264-73.

51 Graham DJ, Reichman ME, Wernecke M et al. Stroke, bleeding, and mortality risks in elderly medicare beneficiaries treated with dabigatran or rivaroxaban for nonvalvular atrial fibrillation. JAMA Intern Med 2016;176:1662-71.

52 Olesen JB, Lip GY, Kamper AL et al. Stroke and bleeding in atrial fibrillation with chronic kidney disease. $N$ Engl J Med 2012;367:625-35.

53 Nielsen PB, Lane DA, Rasmussen LH, Lip GY, Larsen TB. Renal function and non-vitamin $\mathrm{K}$ oral anticoagulants in comparison with warfarin on safety and efficacy outcomes in atrial fibrillation patients: a systemic review and meta-regression analysis. Clin Res Cardiol 2015;104:418-29.

54 Hohnloser SH, Hijazi Z, Thomas L et al. Efficacy of apixaban when compared with warfarin in relation to renal function in patients with atrial fibrillation: insights from the ARISTOTLE trial. Eur Heart J 2012;33:2821-30.

55 Bohula EA, Giugliano RP, Ruff CT et al. Impact of renal function on outcomes with edoxaban in the ENGAGE AF-TIMI 48 trial. Circulation 2016;134:24-36.

56 Hijazi Z, Hohnloser SH, Oldgren J et al. Efficacy and safety of dabigatran compared with warfarin in relation to baseline renal function in patients with atrial fibrillation: a RE-LY (Randomized Evaluation of Long-term Anticoagulation Therapy) trial analysis. Circulation 2014;129:961-70.

57 Eikelboom JW, Wallentin L, Connolly SJ et al. Risk of bleeding with 2 doses of dabigatran compared with warfarin in older and younger patients with atrial fibrillation: an analysis of the randomized evaluation of long-term anticoagulant therapy (RE-LY) trial. Circulation 2011;123:2363-72.
58 National Institute for Health and Care Excellence. Chronic kidney disease in adults: assessment and management. NICE clinical guideline No 182. London: NICE, 2014.

59 Mueck W, Kubitza D, Becka M. Co-administration of rivaroxaban with drugs that share its elimination pathways: pharmacokinetic effects in healthy subjects. Br J Clin Pharmacol 2013;76:455-66.

60 Wang L, Zhang D, Raghavan N et al. In vitro assessment of metabolic drug-drug interaction potential of apixaban through cytochrome P450 phenotyping, inhibition, and induction studies. Drug Metab Dispos 2010;38:448-58.

61 Dans AL, Connolly SJ, Wallentin L et al. Concomitant use of antiplatelet therapy with dabigatran or warfarin in the Randomized Evaluation of Long-Term Anticoagulation Therapy (RE-LY) trial. Circulation 2013;127:634-40.

62 Uchino K, Hernandez AV. Dabigatran association with higher risk of acute coronary events: meta-analysis of noninferiority randomized controlled trials. Arch Intern Med 2012;172:397-402.

63 Hohnloser SH, Oldgren J, Yang S et al. Myocardial ischemic events in patients with atrial fibrillation treated with dabigatran or warfarin in the RE-LY (Randomized Evaluation of Long-Term Anticoagulation Therapy) trial. Circulation 2012;125:669-76.

64 Larsen TB, Rasmussen LH, Gorst-Rasmussen A et al. Myocardial ischemic events in 'real world' patients with atrial fibrillation treated with dabigatran or warfarin. Am J Med 2014;127:329-336 e4.

65 Ruff CT, Giugliano RP, Braunwald E et al. Comparison of the efficacy and safety of new oral anticoagulants with warfarin in patients with atrial fibrillation: a meta-analysis of randomised trials. Lancet 2014;383:955-62.

66 Francart SJ, Hawes EM, Deal AM et al. Performance of coagulation tests in patients on therapeutic doses of rivaroxaban. A cross-sectional pharmacodynamic study based on peak and trough plasma levels. Thromb Haemost 2014;111:1133-40.

67 Hawes EM, Deal AM, Funk-Adcock D et al. Performance of coagulation tests in patients on therapeutic doses of dabigatran: a cross-sectional pharmacodynamic study based on peak and trough plasma levels. J Thromb Haemost 2013;11:1493-502.

68 Skeppholm M, Al-Aieshy F, Berndtsson M et al. Clinical evaluation of laboratory methods to monitor apixaban treatment in patients with atrial fibrillation. Thromb Res 2015;136:148-53.

69 Kitchen S, Gray E, Mackie I et al. Measurement of non-coumarin anticoagulants and their effects on tests of Haemostasis: guidance from the British Committee for Standards in Haematology. Br J Haematol 2014;166:830-41.

70 Warkentin TE, Margetts P, Connolly SJ et al. Recombinant factor VIIa (rFVIIa) and hemodialysis to manage massive dabigatranassociated postcardiac surgery bleeding. Blood 2012;119:2172-4.

71 Wanek MR, Horn ET, Elapavaluru S, Baroody SC, Sokos G. Safe use of hemodialysis for dabigatran removal before cardiac surgery. Ann Pharmacother 2012;46:e21.

72 Zahir H, Brown KS, Vandell AG et al. Edoxaban effects on bleeding following punch biopsy and reversal by a 4 -factor prothrombin complex concentrate. Circulation 2015;131:82-90.

73 Honickel M, Treutler S, van Ryn J et al. Reversal of dabigatran anticoagulation ex vivo: porcine study comparing prothrombin complex concentrates and idarucizumab. Thromb Haemost 2015;113:728-40.

74 Pollack CVJr, Reilly PA, Bernstein R et al. Design and rationale for RE-VERSE AD: a phase 3 study of idarucizumab, a specific reversal agent for dabigatran. Thromb Haemost 2015;114:198-205.

75 Pollack CVJr, Reilly PA, Eikelboom J et al. Idarucizumab for dabigatran reversal. N Engl J Med 2015;373:511-20.

76 Glund S, Stangier J, van Ryn J et al. Restarting dabigatran etexilate $24 \mathrm{~h}$ after reversal with idarucizumab and redosing idarucizumab in healthy volunteers. J Am Coll Cardiol 2016;67:1654-6. 
77 Lu G, DeGuzman FR, Hollenbach SJ et al. A specific antidote for reversal of anticoagulation by direct and indirect inhibitors of coagulation factor Xa. Nat Med 2013;19:446-51.

78 Siegal DM, Curnutte JT, Connolly SJ et al. Andexanet Alfa for the Reversal of Factor Xa Inhibitor Activity. N Engl J Med 2015;373:2413-24.

79 Connolly SJ, Milling TJJr, Eikelboom JW et al. Andexanet alfa for acute major bleeding associated with Factor Xa inhibitors. N Engl J Med 2016;375:1131-41.

80 Ansell JE, Bakhru SH, Laulicht BE et al. Use of PER977 to reverse the anticoagulant effect of edoxaban. N Engl J Med 2014;371:21412.

81 Keeling D, Tait RC, Watson H, British Committee of Standards for Haematology. Peri-operative management of anticoagulation and antiplatelet therapy. Br J Haematol 2016;175:602-13.
82 Heidbuchel H, Berti D, Campos M et al. Implementation of nonvitamin $\mathrm{K}$ antagonist oral anticoagulants in daily practice: the need for comprehensive education for professionals and patients. Thromb J 2015;13:22.

83 Martin K, Beyer-Westendorf J, Davidson BL et al. Use of the direct oral anticoagulants in obese patients: guidance from the SSC of the ISTH. J Thromb Haemost 2016;14:1308-13.

Address for correspondence: Dr Carolyn Millar, Hammersmith Hospital, Imperial College Healthcare NHS Trust, DuCane Road, London W12 0HS, UK.

Email: c.millar@imperial.ac.uk

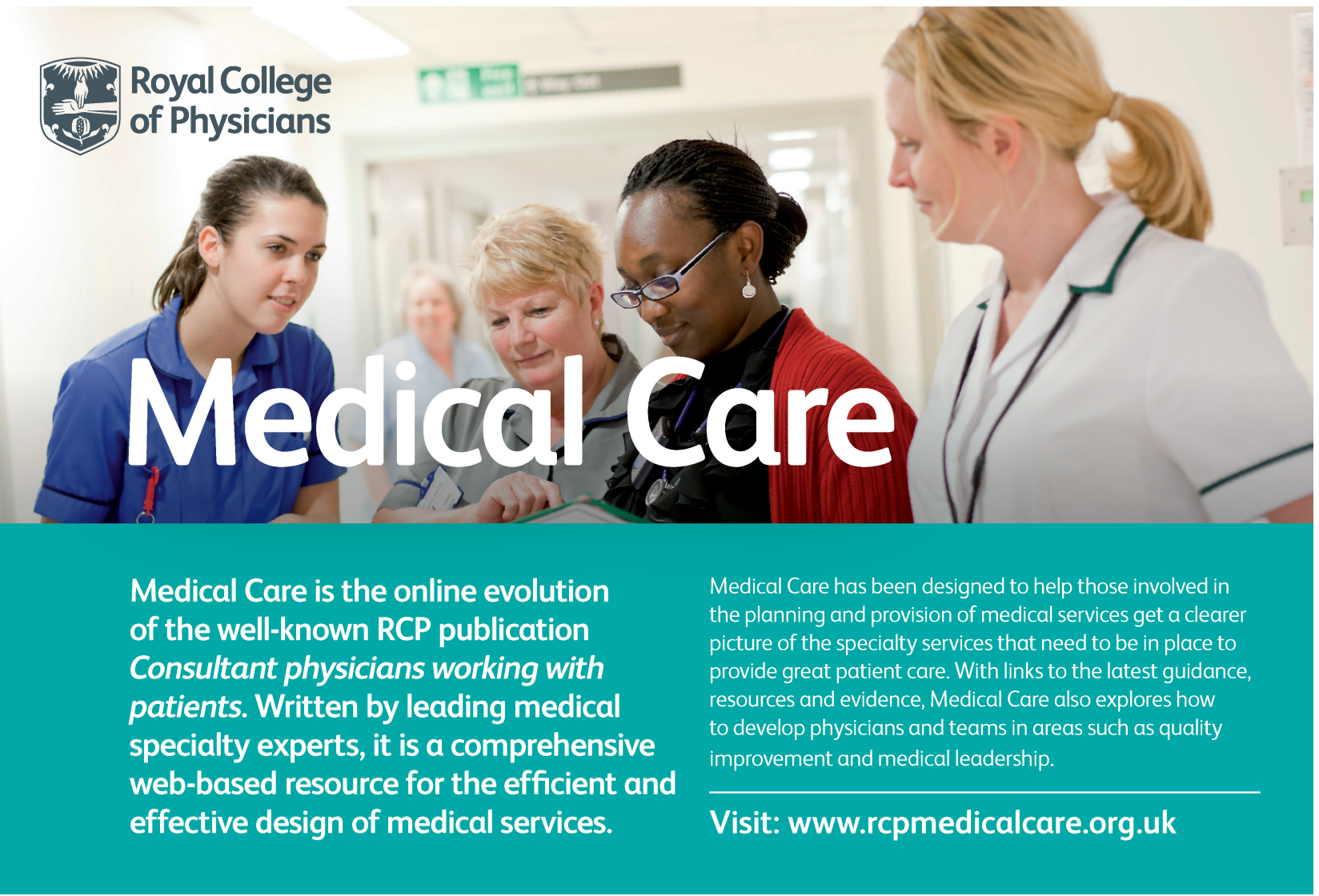

